DOI: $10.15290 /$ bsl.2019.14.09

\author{
Katarzyna Smyczek \\ Wydział Filologiczny \\ Uniwersytet Łódzki \\ e-mail: katarzyna.smyczek@uni.lodz.pl \\ ORCID: 0000-0001-6866-7731
}

\title{
Elegia starozakonna - o szmoncesie w PRL-u
}

Szmonces - gatunek sceniczno-literacki - był niezwykle popularny w teatrzykach kabaretowych dwudziestolecia międzywojennego. Polski słownik judaistyczny definiuje go jako: „kawał, dowcip żydowski, monolog, dialog, piosenka itp. na tematy żydowskie, czerpiący wzorce z żydowskiego humoru" ${ }^{1}$. Należące do tej tradycji, przedwojenne utwory miał w swoim repertuarze kabaret Dudek ${ }^{2}$ - mistrzowskie wykonanie przez Edwarda Dziewońskiego i Wiesława Michnikowskiego dialogu Sęk Konrada Toma zapisało się złotymi zgłoskami w historii polskiej sztuki rozrywkowej. Niniejszy artykuł przypomina o mniej znanych powojennych interpretacjach szmoncesów oraz opisuje odbiór i sposób funkcjonowania tej formy satyrycznej po 1945 roku.

\footnotetext{
1 Szmonces, w: Polski słownik judaistyczny, t. 2, red. Z. Borzymińska, R. Żebrowski, Warszawa 2003, s. 638-639.

2 Kabaret Dudek - Kabaret założony przez Edwarda Dziewońskiego. Premiera pierwszego programu Spotkajmy się na Nowym Świecie odbyła się 13 stycznia 1967 roku w warszawskiej kawiarni "Nowy Świat”, która była główną siedzibą kabaretu. Ostatni spektakl wystawiono 13 stycznia 1975 roku. Dziewoński był zaangażowanym popularyzatorem twórczości przedwojennych artystów kabaretowych. W repertuarze Dudka znajdowały się skecze i piosenki Juliana Tuwima, Mariana Hemara, Konrada Toma, Ludwika Lawińskiego. W 1987 roku próbowano wznowić działalność kabaretu w zmienionej formule i z poszerzonym zespołem aktorskim. 13 listopada zainaugurowano rewię Po trzynastu latach, czyli Dudek wiecznie żywy. Zob. R. Dziewoński, Sęk z Dudkiem, Warszawa 1999, s. 9-28, 212-243.
} 
Dziennikarz magazynu „Pani” w recenzji z 1923 roku definiował szmonces jako „odmianę języka polskiego w interpretacji aktorów Toma, Lawińskiego, Borońskiego i Ursteina"3. Chodziło nie tyle o specyficzny dla wszystkich wymienionych artystów styl gry, ale o ogólne zasady prezentacji szmoncesów, które wypracowano w ówczesnych teatrzykach kabaretowych. Parodiowano sposób wypowiedzi członków "snobującego się odłamu" 4 żydowskiej diaspory, którzy zrezygnowali z porozumiewania się między sobą w języku jidysz. Osoby te posługiwały się polszczyzną nie do końca poprawnie, często popełniając błędy gramatyczne i leksykalne lub siląc się na hiperpoprawność. Poprzez prześmiewcze wyjaskrawianie specyficznego akcentu, np. zmiękczanie głosek $\mathrm{z}$ szeregu szumiącego czy przeciąganie samogłosek, artyści kabaretowi próbowali odtworzyć na scenie melodię języka ulicy. Twórcy międzywojnia podkreślali, że aktorzy szmoncesowi musieli wykazać się wyjątkowymi umiejętnościami warsztatowymi, by z tekstu będącego przykładem żydowskiego poczucia humoru nie uczynić pamfletu ośmieszającego Żydów ${ }^{5}$.

Na znaczenie elementów pozatekstowych w omawianych formach literacko-estradowych zwracał uwagę powojenny interpretator szmoncesów wspomniany już Wiesław Michnikowski:

3 D. Fox, Kabarety i rewie międzywojennej Warszawy. Z prasowego archiwum Dwudziestolecia, Katowice 2007, s. 166. Szerzej o szmoncesie w dwudziestoleciu międzywojennym: tamże, s. 166-174; D. Fox, Teatralny rodowód Lopka. Na marginesie szmoncesu, w: Żydzi w lustrze dramatu, teatru i krytyki teatralnej, red. E. Udalska i A. Tytkowska, Katowice 2004, s. 185-202; A Uścińska, Elegia starozakonna, czyli szmonces w kabarecie polskim jako żart z pogranicza kultur, w: Jaki jest kabaret?, red. D. Fox i J. Mikołajczyk, Katowice 2012, s. 93-114; A. Uścińska, Szmonces w polskim kabarecie dwudziestolecia międzywojennego, w: Humor polski, red. D. Brzozowska i W. Chłopicki, Kraków 2014, s. 495-517. Szmoncesem z perspektywy językoznawczej zajmowała się Anna Krasowska, Obraz dziecka żydowskiego w wybranych tekstach szmoncesowych, w: Żydowskie dziecko, red. A. Jeziorkowska-Polakowska, A. Karczewska, Lublin 2013, s. 159-167; Socjolingwistyczne i stylistyczne aspekty nazewnictwa Żydów w szmoncesie kabaretowym dwudziestolecia międzywojennego, w: Niejedno ma imię... Prace onomastyczne i dialektologiczne dedykowane Profesor Ewie Wolnicz-Pawtowskiej, Warszawa 2013, s. 229-245; Obraz Żyda w szmoncesie kabaretowym, „Prace Językoznawcze" 2011, z. 13, s. 125-139.

4 K. Krukowski, Mała antologia kabaretu, Warszawa 1982, s. 187.

5 „Kiepskim autorom i aktorom wydawało się, że szmonces to nic innego jak tzw. «żydłaczenie», to znaczy bezmyślne przekształcanie słów [...]. Taki szmonces [...] zamiast bawić jątrzył i judził. Klasyczny szmonces w wydaniu Tuwima lub Hemara, w wykonaniu Lawińskiego, Toma, czy moim, to nie złośliwe wyśmiewanie się z «Żydków», ale satyra na snobujący się odłam społeczeństwa żydowskiego, z jego śmiesznostkami, specyficzną filozofią, z jego «parlez français, językowym superpuryzmem»", tamże, s. 187; W. Michnikowski o interpretacji aktorskiej szmoncesów: „Szmonces nie polega na tym, żeby przedrzeźniać... to jest w mentalności, to jest twierdzenie ze znakiem zapytania właściwie. To się wiąże przede wszystkim z tym, jak mówić szmonces. Myśmy mieli to w uszach. Słyszeliśmy przed wojną" [R. Dziewoński, P. Dziewoński, Dożylnie o Dudku - Edwardzie Dziewońskim, Warszawa 2007, s. 15]. 
Te teksty właściwie same sugerują, w pewnym sensie, wykonanie. Pamiętam, jak kiedyś w telewizji, to było dawno, dawno temu, robiłem z Ireną Kwiatkowską taki skecz Tuwima. To się nazywało Noc poślubna. No więc proszę sobie wyobrazić, mieliśmy to nagranie już prawie w nocy. I jak to $\mathrm{w}$ telewizji musieliśmy kilka razy powtarzać. A w studiu była jakaś pani z cenzury, która za każdym razem nam zarzucała, że to w jaki sposób mówimy ten skecz, ubliża Żydom. Ja się w końcu zdenerwowałem i mówię: „Proszę pani, Tuwim to napisał, Żyd, prawda? I ten tekst gdyby go ksiądz z ambony przeczytał to też będzie szmonces!" 6 .

Utwór, o którym mówił aktor, stanowił część spektaklu Teatru Telewizji Cabaret warietano, czyli XI muza Juliana Tuwima ${ }^{7}$. Przedstawienie było złożone z piosenek, monologów i skeczy kabaretowych Tuwima napisanych przed 1939 rokiem, które zostały zinterpretowane na nowo przez młodych aktorów, takich jak Wojciech Pokora i Barbara Rylska. W widowisku wystąpili także artyści słynnego teatrzyku Qui Pro Quo Adolf Dymsza, Tadeusz Olsza i Kazimierz Krukowski.

Skecz Tuwima to szmoncesowy „dramacik” obyczajowy. Akcja rozgrywa się podczas pierwszej wspólnej małżeńskiej nocy Izaaka i Dorci. Panna młoda, nie chcąc rozpoczynać nowego życia w kłamstwie, postanawia wyznać małżonkowi, że „była niegdyś uwiedzioną” ${ }^{8}$, czego konsekwencją jest czwórka dzieci, trzy dziewczynki i jeden chłopczyk. Nieznane są personalia ojca - bądź ojców - Dorcinego potomstwa. Mąż zdaje się nie przejmować niespodziewanymi nowinami, martwi go jedynie, w jaki sposób z pensji krawca zdoła wyżywić aż 6 osób. Pokłada nadzieję w swoim teściu, który w zamian za to, że Izaak „zakochał się w panienkę co ma 41 lat" ${ }^{\prime 9}$, obiecał mu weksel na 2000 złotych oraz wykup lokalu na pracownię krawiecką. Niestety "tatuś" Dorci znany jest z tego, że jeszcze nigdy nie dotrzymał danego słowa.

${ }^{6}$ W. Michnikowski, Poprosze zamiejscowa Lubartów czydzieściczy, rozm. A. Uścińska, „Teatr” 2008, nr 12, s. 71.

7 Cabaret Warietano, czyli XI Muza Juliana Tuwima, program telewizyjny, Warszawa TVP Kultura, [emisja: 27.01.2015, godz. 12:40]; miejsce premiery: Teatr Telewizji; data premiery: 25 października 1967; reżyseria: Jerzy Dobrowolski; scenariusz: Rudolf Gołębiowski; realizacja TV: Edwarda Paszkowska; scenografia: Franciszek Starowieyski; muzyka; Edward Pałłasz; obsada aktorska: Jerzy Dobrowolski, Wiesław Michnikowski, Irena Kwiatkowska, Józef Nowak, Wojciech Pokora, Barbara Rylska, Andrzej Stockinger, Jolanta Zykun, Tadeusz Olsza, Kazimierz Krukowski, Adolf Dymsza. Zob. Encyklopedia Teatru, http://www.encyklopediateatru.pl/przed stawienie/232/cabaret-warietano-czyli-xi-muza-juliana-tuwima [dostęp 16.12.2019].

8 Cyt. za: J. Tuwim, [Noc poślubna], w: tegoż, Kabaretiana, oprac. T. Stępień, Warszawa 2002, s. 200.

9 Tamże. 
Izaak zdaje się być pogodzony ze swoim losem, zgodnie ze szmoncesową filozofią, która wybrzmiewa w maksymie: ,jak się nie ma, co się lubi, to się lubi co się ma" ${ }^{10}$.

Z wypowiedzi Michnikowskiego można wywnioskować, że uważał on opinię cenzorki za niedorzeczną - wszak autorem "problematycznego" tekstu nie był antysemita, zaś realizatorzy spektaklu nie używali żydowskiego humoru z poczucia wyższości, lecz po to, by przypomnieć współczesnym widzom o niezwykle udanym romansie Juliana Tuwima z podkasaną muzą. Potępienie antysemickiej wymowy skeczu jest znamienne w kontekście ówczesnej sytuacji politycznej. Premiera Cabaretu Warietano odbyła się 25 października 1967 roku, kiedy trwała inspirowana przez władze partyjne kampania antysyjonistyczna, którą w przemówieniu z 19 czerwca rozpoczął Władysław Gomułka ${ }^{11}$. Organizowano też zebrania partyjne i pracownicze, na których potępiano izraelską agresję na państwa arabskie podczas wojny sześciodniowej, a przedstawicielom "V kolumny", tj. polskim Żydom, którzy nie opowiadali się po stronie arabskiej, zalecano opuszczenie kraju. Brak entuzjastycznego poparcia dla polityki dyplomatycznej PRL mógł być nawet przyczyną represji ${ }^{12}$. Jerzy Eisler w swojej monografii na temat 1968 roku opisuje przykłady partyjnego polowania na syjonistyczne czarownice. Podczas wieców partyjnych absurdy piętrzyły się tak jak w dowcipie szmoncesowym - np. pewna osoba z powodów osobistych nie mogła uczestniczyć w jednym z czerwcowych spotkań. Kilka dni później musiała wyjaśnić swoją nieobecność. Uczestniczący w przesłuchaniu lektor komitetu dzielnicowego PZPR Warszawa-Mokotów stwierdził, że z pewnością musi być ona syjonistką, ponieważ: „Włosy towarzyszki i karnacja świadczą, że towarzyszka jest Polką pochodzenia żydowskiego, temu towarzyszka nie zaprzeczy. Polacy pochodzenia żydowskiego właśnie celowo na te zebrania nie przychodzą" ${ }^{\prime 13}$. Kobieta złożyła skargę na domorosłego eksperta antropologii fizycznej. Okazało się, że nie była Żydówką, zaś lektor ustalił jej pochodzenie na podstawie opalenizny i pofarbowanych na czarno włosów ${ }^{14}$.

\footnotetext{
10 „Jak się nie ma, co się lubi, to się lubi, co się ma. Tę zasadę zawsze kładę, co się tyczy moje ja; Bo trzeba mieć to minimum, potrzeba mieć to minimum, potrzeba mieć ten smak, to wyczucie kiedy nie, a kiedy tak!" (fragment szmoncesu wykonywanego przez Kazimierza Krukowskiego [cyt. za: R.M. Groński, Jak w przedwojennym kabarecie, Warszawa 1978, s. 88-89].

11 Zob. J. Eisler, Polski rok 1968, Warszawa 2006, s. 88-140.

12 Tamże, s. 110.

13 Tamże.

14 Tamże.
} 
Skecz Noc poślubna w wykonaniu Michnikowskiego i Kwiatkowskiej mógł, wziąwszy pod uwagę kontekst polityczno-społeczny, zostać odczytany - wbrew woli samych twórców - jako usankcjonowany przez władzę przejaw dyskryminacji Żydów, zgodny z polityką władz. Zastanawiająca jest zatem przyczyna ingerencji. Być może wynikała ona z osobistych przekonań cenzorki, a być może świadczy o tym, że większy wpływ na cenzurę miała wówczas rządowa frakcja "puławian” 15 .

Szmonces był - jak stwierdza Knut Grimstad, norweski badacz twórczości Juliana Tuwima - sposobem oddziaływania na to, jak postrzegano mniejszość żydowską. Pozwalał twórcom zdefiniować i kontrolować stereotypy dotyczące tej grupy etnicznej ${ }^{16}$. Omawiany typ humoru mógł jednak stać się narzędziem antysemickich wystąpien, tak jak miało to miejsce w latach trzydziestych. Zwłaszcza publikacje endeckie przodowały w niewybrednych żartach i złośliwym wyśmiewaniu błędów językowych ${ }^{17}$.

Cenzorka uznała, że występ Michnikowskiego i Kwiatkowskiej ubliża Żydom, być może dlatego, że nie znała przedwojennej kultury kabaretowej. Kazimierz Rudzki w rozmowie z Antonim Słonimskim i Kazimierzem Korcellim podkreślał, że po doświadczeniach II wojny światowej zmieniła się recepcja szmoncesowego dowcipu:

Dzisiaj, kiedy te rzeczy przeszły do tragicznej historii, nie należy mówić żartobliwie o świecie umarłych i trudno wymagać od generacji, która nie znała prototypów, żeby rozróżniała humor wyblakłych odbitek sprzed lat. Jest to niemądre i nietaktowne ${ }^{18}$.

Bywalcy Qui Pro Quo i innych warszawskich nad-scenek stanowili w zestawieniu z liczbą ludności II Rzeczpospolitej dość niewielką grupę.

15 Puławianie - nieformalna, opozycyjna wobec „natolińczyków” frakcja w Polskiej Zjednoczonej Partii Robotniczej, która wyłoniła się po 1956 roku w wyniku konfliktu wewnątrzpartyjnego. Nazwy frakcji pochodzą od miejsc spotkań ich przedstawicieli - Natolina, gdzie mieścił się pałac Rady Ministrów oraz ulicy Puławskiej w Warszawie, przy której mieszkali wysocy urzędnicy partyjni. „Puławianie” po 1956 roku deklarowali chęć demokratyzacji i liberalizacji życia politycznego. Ze względu na ich przeszłość w okresie stalinowskim, szczerość tych zapewnień była dyskusyjna. Koteria „natolińska” dążyła do zrzucenia całkowitej odpowiedzialności za wypaczenia okresu stalinowskiego na grupę „puławską”, w której znajdowało się wielu Polaków pochodzenia żydowskiego. Po marcu 1968 wyłączną winą za nieprawości i represje obciążano "syjonistów”, tj. działaczy pochodzenia żydowskiego [zob. J. Eisler, „Polskie miesiace" czyli kryzys(y) w PRL, Warszawa 2008, s. 24-35].

16 K.A. Grimstad, Polsko-żydowskie gry kabaretowe, czyli Juliana Tuwima próba akulturacji, „Teksty Drugie" 2009, nr 3, s. 62.

17 Więcej na ten temat zob. A Uścińska, Elegia starozakonna, czyli szmonces w kabarecie polskim.

18 K. Korcelli, K. Rudzki, A. Słonimski, Wspomnienia o kabarecie (rozmowa), „Dialog” 1972, nr 10, s. 121. 
Na prowincjonalnych estradach królowała szmoncesowa szmira ${ }^{19}$ - nawet jeśli cenzorka widziała przedwojenne wykonania szmoncesów, mogła nie mieć szansy na zobaczenie ich $\mathrm{w}$ interpretacji mistrzów tego gatunku.

Noc poślubna nie została usunięta z programu Cabaretu Warietano, w skeczu dokonano jednak kilku subtelnych zmian. Aktorzy interpretowali tekst, nie posługując się „szmoncesowymi” znakami teatralnymi. Zrezygnowano $z$ charakterystycznego dla tej formy scenicznej sposobu intonacji. Ingerowano również w warstwie tekstowej - poprawiono większość celowych błędów językowych. Imię głównego bohatera zastąpiono takim, które funkcjonuje zarówno w tradycji żydowskiej, jak i chrześcijańskiej - Izaak stał się zasymilowanym Jakubem:

[wersja przedwojenna]

Mąż: Jak się już zakochałem

w panienkę co ma 41 lat [...]

Żona: Izaaku, nie rań moje serce

z tą chronologią. Ja chcę ci coś wszak oświadczyć - ja byłam niegdyś uwiedzioną... ale to było wbrew, nawet $\mathrm{w}$ obie brwi mojej woli... to był brutalny gwałt, Izaaku.

Lecz ty mi wybaczysz wszak ${ }^{20}$. [wersja z 1967 roku]

Mąż: Jak ja się zakochałem

w panienkę co ma 41 lat [...]

Żona: Jakub, przestań ranić moje serce

$z$ tą chronologią. Ja chcę ci coś wszak oświadczyć - ja byłam niegdyś uwiedziona... ale to było wbrew, nawet $\mathrm{w}$ obie brwi mojej woli... to był brutalny gwałt. Jakub, ale ty mi wybaczysz? ${ }^{21}$

Zarówno twórcy, jak i badacze gatunku podkreślają, że szmonces najpełniej realizuje się na estradzie. Związek Jakuba i Dorci nadal miał charakter wymiany handlowej, na której - przede wszystkim finansowo - stracił pan młody ${ }^{22}$. W warstwie tekstowej nowa wersja Nocy poślubnej wciąż była dowcipem żydowskim. Odarta jednak z tak istotnej dla szmoncesu specyficznej interpretacji aktorskiej, nie zapadła w pamięć widzów.

Recepcja szmoncesu nie zależy tylko od wykonania, ale także od odbiorców, czasu i miejsca inscenizacji. Realizatorzy Cabaretu Warietano wybrali niefortunny moment na przypomnienie Tuwimowego skeczu. Zdarzało się przecież, że artyści estradowi w PRL-u z powodzeniem powracali do dawnych tradycji kabaretowych ${ }^{23}$.

19 D. Fox, Kabarety i rewie międzywojennej Warszawy, s. 166 [wyróżn. - K.S.].

${ }^{20}$ Cyt. za: J. Tuwim, Noc poślubna, w: R.M. Groński, Jak w przedwojennym kabarecie, Warszawa 1978, s. 76-78.

${ }^{21}$ Cyt. za: Cabaret Warietano, czyli XI Muza Juliana Tuwima.

22 O poetyce szmoncesu zob. T. Stępień, Kabaret Juliana Tuwima, Katowice 1989, s. 56-64.

23 „Przypomnieć to, co było najwspanialsze w przedwojennym kabarecie. Teksty piosenek, które można zaliczyć do najpiękniejszych wierszy. Polszczyzna Hemara, Tuwima. Przekazać 
13 stycznia 1965 w kawiarni na warszawskim Nowym Świecie odbyła się premiera pierwszego programu Kabaretu Dudek. W drugiej części rewiowej składanki zaprezentowano skecz Sęk Konrada Toma w interpretacji Edwarda Dziewońskiego i Wiesława Michnikowskiego. Bohaterowie utworu, Kuba Goldberg i Beniek Rappaport to postaci seryjne, które wielokrotnie powracały na estrady stołecznych teatrzyków varietes, by prowadzić niedorzeczne negocjacje biznesowe. W pierwszej scenicznej realizacji Sęka zagrali Ludwik Lawiński i Lopek Krukowski.

Recenzent „Trybuny Ludu” Tomasz Szydłowski zanotował, że szmonces ten w interpretacji Michnikowskiego i Dziewońskiego: „Wywoływał [...] na sali prawie bez przerwy wybuchy frenetycznego śmiechu, choć był prawie seansem $z$ duchami, bo mówił o ludziach i sprawach, których już nigdzie nie ma" ${ }^{24}$. Dudek również spotkał się z zrzutami o antysemityzm, kiedy grano Sęka przed polonią amerykańską w 1966 roku. Jan Kobuszewski, który występował wtedy z Dziewońskim w zastępstwie za Michnikowskiego wspominał, że po jednym z przedstawień doszło do dość nieprzyjemnego incydentu:

Przyszły dwie panie, Żydówki. Zrobiły nam potworną awanturę, że to jest antysemityzm, że to jest wyśmiewanie się z Żydów. Osłupieliśmy. Dudek zapowiadając Sęka, mówił, że jest to tekst ze złotej księgi humoru i polskiego, i żydowskiego, a tu taki numer. Panie oświadczyły, że napiszą do Kongresu Żydów Amerykańskich skargę w tej sprawie. To było przy ludziach $\mathrm{w}$ garderobie. Cicho się zrobiło, a tu odzywa się jakaś pani, która wcześniej gratulowała nam występu i mówi: „To się świetnie składa, proszę pań, ja jestem przewodniczącą tego Kongresu [...] i mnie się to okropnie podobało, a mój mąż do dzisiaj się zachowuje, jak jeden z tych panów, więc mogą panie darować sobie pisanie, bo według mnie jest to znakomity tekst" 25 .

Nie można lekceważyć wrażliwości odbiorców oraz ich doświadczeń. Część widzów uważała ten typ humoru za niestosowny. Należy jednak zauważyć, że gdyby Dudek nie zdecydował się na wystawienie utworu Toma na scenie, peerlowska publiczność nie poznałaby gatunku estradowego, który był częścią kultury dwudziestolecia międzywojennego.

\footnotetext{
choć cień tamtego blasku nowym autorom. Dać możliwość mistrzowskiego popisu w dwu-, trzyminutowym skeczu, monologu. Przywrócić pointy, delikatne aluzje, mądrze rozśmieszać. Takim podskórnym nurtem płynęło wspomnienie kabaretu przedwojennego w Dudku" [R. Dziewoński, Sęk z Dudkiem, s. 12].

24 Tamże, s. 34.

25 Tamże, s. 54.
} 
Kabaretowi Dziewońskiego zawdzięczamy przywrócenie pamięci historyczno-literackiej o wielu doskonałych, przedwojennych utworach. W każdym spektaklu Dudka był punkt poświęcony tradycji polskiej sztuki rozrywkowej. Piąty, jubileuszowy program składał się aż z pięciu utworów napisanych przed 1939 rokiem. Nie zabrakło oczywiście uwielbianego przez publiczność Sęka ${ }^{26}$. Premiera widowiska Naokoło czterech Dudków odbyła się 13 marca 1969 roku.

13 stycznia 1975 roku podczas przedstawienia kabaretu w kawiarni na Nowym Świecie Wiesław Michnikowski po kolejnym nagrodzonym gromkimi brawami Sęku zaśpiewał szmoncesowe kuplety Słowo musi być święte, które wykonywał przed wojną Ludwik Lawiński27. Był to ostatni spektakl Dudka, dlatego Michnikowski zamierzał „ugotować” Dziewońskiego na scenie:

Dostałem ten tekst Lawińskiego od mojego przyjaciela doktora Rożniatowskiego [...]. Poprosiłem Wojtka [Młynarskiego] o dopisanie czego należy i ostatecznie we trzech - wtajemniczyliśmy Tadzia Suchockiego - przygotowaliśmy całość 28 .

Młynarski dopisał do kupletów Lawińskiego trzy nowe zwrotki. Utrzymana $\mathrm{w}$ szmonce-poetyce piosenka opowiada o legendarnym wydarzeniu, przełomowym dla historii polskiego powojennego kabaretu literackiego pierwszym spotkaniu Michnikowskiego i Dziewońskiego:

Raz wypiłem parę wódek

$\mathrm{z}$ jednym takim niech go szlag!

co go było - dzięcioł, dudek?

W każdym razie coś od ptak.

On mnie idzie mówić - Wiesiek!

on się wbija we mnie wzrok:

Zagraj w moi interesie,

dziecko drogie jeden rok.

I nim błysnął świt różany,

ja już byłem oplątany.

On mnie cabas w każdy szabas

do geszeftu gnał jak kat $[\ldots]^{29}$.

\footnotetext{
${ }^{26}$ Sęk w wykonaniu Dudka i Michnikowskiego trafił nawet na pocztówkę dźwiękową. Zob.

R. Dziewoński, P. Dziewoński, Dożylnie o Dudku Edwardzie Dziewońskim, s. 16.

27 R. Dziewoński, Sęk z Dudkiem, s. 226-228.

28 Tamże, s. 227.

29 Tamże, s. 226.
} 
Znaczące, że to właśnie szmoncesem uczczono 10. jubileusz kabaretu Dudek. Dziewoński i Michnikowski stali się specjalistami w tym gatunku sceniczno-literackim. Kazimierz Krukowski miał nawet wyznać Michnikowskiemu, że wykonują szmoncesy prawie tak dobrze jak on sam ${ }^{30}$. W programie Po 13 latach czyli Dudek wiecznie żywy z 1987 zagrali jeszcze w Elegii starozakonnej i U lekarza Juliana Tuwima ${ }^{31}$.

Tekst Młynarskiego to niejedyny szmonces, który powstał w Polsce po II wojnie światowej. 12 kwietnia 1959 roku w łódzkim tygodniku "Odgłosy" opublikowano fragment Z szopki polityczno-literackiej $1958^{32} \mathrm{Ry}$ szarda Marka (pseudonim Ryszarda Wierzbowskiego i Marka Grońskiego) ${ }^{33}$, na którą składały się między innymi dwie piosenki szmoncesowe inspirowane postacią „Lopka” Krukowskiego. Szopka pełniła funkcję komentarza do aktualnych wydarzeń, zaś Krukowski został jej bohaterem prawdopodobnie ze względu na objęcie kierownictwa artystycznego nad sceną Teatru Buffo w 1958 roku. Krukowski zarządzał wówczas aż dwoma stołecznymi teatrami. Od 1 czerwca 1957 roku również sprawował funkcję dyrektora Teatru Syrena ${ }^{34}$.

Autorzy opowiadali o zawodowym powodzeniu Lopka, nawiązując do szmoncesów, które artysta wykonywał w kabaretach przed 1939 rokiem. Pierwsze strofy tekstu Ryszarda Marka stanowią parafrazę piosenki Konrada Toma Jak się nie ma, co się lubi35:

30 W. Michnikowski, Poproszę zamiejscowa Lubartów czydzieściczy..., s. 72.

31 R. Dziewoński, Sęck z Dudkiem, s. 240.

32 Ryszard Marek, Z szopki polityczno-literackiej 1958, „Odgłosy” 1959, nr 15 (59), 12 kwietnia 1959, s. 11.

33 Rzyszard Wierzbowski i Marek Groński pod pseudonimem Ryszard Marek tworzyli wspólnie teksty satyryczne i kabaretowe. Zadebiutowali 16 sierpnia 1956 r. wierszem Niespodzianka opublikowanym na łamach łódzkiego dwutygodnika społeczno-literackiego „Kronika”. Ich teksty ukazywały się na łamach czasopism: „Kronika”, „Szpilki”, „Karuzela”, „Odgłosy”, „Nowa Kultura". Byli autorami szopek politycznych, m.in. Kontrabandy, której premiera w łódzkim Teatrze Nowym była debiutem reżyserskim Bogdana Baera. W łódzkim Teatrze 715 wystawiono ich rewię satyryczną Polowanie z nagonką. W 1966 r. nakładem Wydawnictwa Łódzkiego ukazał się tom Seria serio (zawiera wiersze satyryczne w cyklach Seria serio, Genialne kontynuacje, Przykładne przekłady - tłumaczenia z utworów E. Jewtuszenki i Bułata Okudżawy, Fraszki Frasobliwe, Fraszkopisarstwo nasze, czyli pro domo sua). Wierzbowski i Groński współpracowali z kabaretami, Teatrem Telewizji oraz Polskim Radiem.

34 D. Michalski, Kazimierz Krukowski, w: tegoż, Powróćmy jak za dawnych lat... Historia polskiej muzyki rozrywkowej (1900-1939), Warszawa 2007, s. 401.

35 Por. K. Tom, Jak się nie ma, co się lubi.., w: R.M. Groński, Jak w przedwojennym kabarecie, Warszawa 1978 , s. 88-89. 
Jak się nie ma co się lubi,

To się lubi co się ma!

$\mathrm{Z}$ te zasade teatr kłade.

I nie jeden, ale dwa.

Wiem to nie jest za mecyje,

Nie jest co ja bym pragł

Może jeszcze co do ilość

Absolutnie co do smak ${ }^{36}$.

Ludwik Sempoliński stwierdził, że przełom lat pięćdziesiątych i sześćdziesiątych to okres "największego rozmachu organizacyjnego" Krukowskiego jako dyrektora artystycznego teatrów ${ }^{37}$. Lopka z szopki polityczno-literackiej Ryszarda Marka wyróżniały typowe dla bohaterów szmoncesów właściwości charakteru - umiarkowanie zdrowa ambicja oraz zaradność i umiejętność dostosowania się do zmiennych okoliczności:

Ja sprytu nie mam. Ja powiadam: „Trudno, Kropka Szmonces nie w modzie teraz - więc Odyssa gram. Wśród pań, jak widzę, jest niejedna Panalopka, Więc dawno zaszedł już ten pretendens względem dam" ${ }^{38}$.

Krukowski doskonale wpisywał się w archetyp tułacza. Podobnie jak mityczny Odyseusz, po zakończeniu wojny, wędrował przez ponad dekadę zanim wrócił do ojczyzny. Wyjechał z Warszawy 19 listopada 1939 roku. Od roku 1940 prowadził Teatr Miniatur w Białymstoku. Stamtąd wyruszył do Lwowa, gdzie występował razem z orkiestrą Tea Jazz Adiego Rosnera. 27 października 1941 roku przybył do Buzułuku. Miasto było wówczas siedzibą dowództwa i sztabu Armii Polskiej gen. Władysława Andersa. Krukowski został kierownikiem Teatru Polowego, który przeszedł z wojskami II Korpusu Polskich Sił Zbrojnych szlak bojowy przez Iran, Irak, Syrię, Palestynę, Egipt i Włochy. W 1946 roku artystów polskiej rewii przetransportowano do Londynu. 13 marca 1948 roku przenieśli się do Buenos Aires, gdzie Krukowski założył komediowy Teatr Rozmaitości. Do Polski przybył dopiero 28 września 1956 roku $^{39}$. Pierwszy występ Krukowskiego w Warszawie odbył się w Sali Kongresowej. Na scenie wystąpiły również gwiazdy przedwojennych rewii kabaretowych: Stefania Górska, Helena Grossówna,

\footnotetext{
36 Ryszard Marek, Z szopki polityczno-literackiej 1958.

37 Zob. D. Michalski, Kazimierz Krukowski, s. 402.

38 Ryszard Marek, Z szopki polityczno-literackiej 1958.

39 Zob. D. Michalski, Kazimierz Krukowski, s. 401; K Krukowski, Z Melpomena na emigracji, Warszawa 1987, s. 21-150.
} 
Adolf Dymsza i Tadeusz Olsza. Lopek przypomniał widzom swoje najsłynniejsze szmoncesy (m.in. Jak się nie ma, co się lubi, Minimum, Wekselek) ${ }^{40}$.

W satyrze twórcy objaśniają przyczyny Lopkowej odysei, używając typowo szmoncesowego eufemizmu:

Długo się człowiek po ogromnym świecie tułał,

Zanim zmęczony do rodzinnych wrócił stron.

Bo primo: taki narodowy jest rytuał,

Dwa: dla Odyssa też synekwanon ${ }^{41}$.

Łaciński zwrot sine qua non - tutaj w spolszczonej, zniekształconej formie - został zapożyczony z socjolektu prawniczego. Wykorzystano stereotyp oparty na przekonaniu, że w palestrze dominują Żydzi. Bohater stwierdzał, że podróż była dla niego - współczesnego Odysa - „warunkiem koniecznym". Krukowski opuścił ojczyznę na wiele lat, by ratować się przed zagładą. Doświadczenie Holocaustu stało się również udziałem twórców szopki. Jerzy Tynecki w artykule poświęconym Ryszardowi Wierzbowskiemu cytował jego wspomnienia dotyczące czasu okupacji:

Urodziłem się 26 VIII 1936 roku w Moskwie, dokąd moi rodzice [...] wyjechali w związku z wyróżnieniem pracy ojca na międzynarodowym konkursie architektonicznym i skąd wraz ze mną powrócili do Warszawy, gdzie w 1943 roku zostali zgładzeni podczas likwidacji tzw. „placówki na Narbutta”. Z Warszawy zostałem wysiedlony podczas powstania ${ }^{42}$.

Odys ze szmoncesu Ryszarda Marka nie mógł powrócić do Itaki. Był skazany na los Żyda - wiecznego tułacza, który nigdzie nie jest u siebie. Po powrocie do domu, powitał go syn, szmoncesowy Telemach, Hipek. To właśnie on uświadomił Lopkowi, że miejsca, którego tak długo szukał, już nie ma:

Tamtego z baśni oczekiwał syn Telemach, Mnie witał Hipek - pamiętacie: Lopka syn.

Rzekł z miejsca: „Zaraz uświadomię cię w problemach

Lecz wpierw się pozbądź swoich gestów i tych min.

Ty zmień ten akcent - to się u nas dziś zwalczia,

Melonik radzę ci na zawszę zdjąć.

Zapomnij sobie, że istniała jakaś Malczia

I z tym pytaniem na pytanie wiecznym skończ.

\footnotetext{
40 Tamże, s. 151.

41 Ryszard Marek, Z szopki polityczno-literackiej 1958.

42 Cyt. za: J. Tynecki, Ryszard Wierzbowski 1936-1988, „Prace Polonistyczne” 1988, t. 43 (1987), s. 362.
} 
Stare piosenki zwłaszcza te szmoncesowe

Się nie nadają. Z nimi dziś byś na psy zszedł.

Zmień repertuar: śpiewaj «Toskie» lub «Trawiate»

«Swobodny wiatr» lub «Zaczarowany flet»" 43 .

Bohater miał zapomnieć o ukochanej Penelopie - Malci, z którą złączył się na śmierć i życie. Powinien pozbyć się wszystkiego, co wskazywałoby na jego żydowskie pochodzenie. Całkowicie zasymilowany syn doradza ojcu zmianę repertuaru. Mógłby dzięki temu wreszcie zrealizować się w roli „polskiego Carusa". Kazimierz Krukowski rozpoczynał karierę sceniczną jako tenor w objazdowym zespole operowym Tadeusza Wierzbickiego ${ }^{44}$.

Lopek stał się w utworze Wierzbowskiego i Grońskiego symbolem nie tylko końca epoki szmoncesu, ale także całej przedwojennej kultury kabaretowej. W 1957 roku mistrz żydowskiego dowcipu wydał książkę biograficzną Moja Warszawka. Kończąc swoje wspomnienia, napisał:

Runął pod bombami kruszący się gamach na Karowej. Płonęły całe dzielnice. Padły w gruzy kamienice, teatry, kina, kawiarnie, paliły się kioski uliczne, zamarł śmiech, umilkła piosenka. Moja rokokowa, bawiąca się i śmiejąca Warszawka przestała istnieć ${ }^{45}$.

Podobna konstatacja wybrzmiewa również $\mathrm{w}$ ostatnich wersach tekstu Ryszarda Marka:

Bo przecież dla mnie $w$ tych teatrach miejsca nie ma, Zniknął ten humor i ten specyficzny żart.

$\mathrm{Ba}$ - nad piosenką wisi nawet anatema...

A bez piosenek swoich cóż jest Lopek wart? ${ }^{46}$

Po 1945 roku, wraz z zanikaniem kontekstu kulturowego szmoncesu w Polsce, satyrycy coraz rzadziej sięgali po tę formę sceniczno-literacką. Udaną próbą powrotu do dawnych tradycji były widowiska kabaretu Dudek. Ze względu na traumę II wojny światowej zmieniła się jednak recepcja gatunku. Nawet uwielbiany przez publiczność Dudek musiał zmierzyć się z oskarżeniami o antysemityzm. Jednakże należy zaznaczyć, że niewątpliwą zasługą Edwarda Dziewońskiego jest przywrócenie pamięci historyczno-lite-

\footnotetext{
43 Ryszard Marek, Z szopki polityczno-literackiej 1958.

44 Kazimierz Krukowski, „Almanach Sceny Polskiej 1984/1985”, t. 26, Warszawa 1989, s. 270-271 .

45 K. Krukowski, Moja Warszawka, Warszawa 1958, s. 123.

46 Ryszard Marek, Z szopki polityczno-literackiej 1958.
} 
rackiej o utworach, które wyszły spod pióra Juliana Tuwima, Konrada Toma oraz Ludwika Lawińskiego i były nieodłączną częścią przedwojennej kultury kabaretowej.

\section{Bibliografia}

Borzymińska Zofia, Żebrowski Rafał [red.] (2003), Polski słownik judaistyczny, t. 2, Warszawa: Prószyński i S-ka, s. 638-639.

Dziewoński Roman (1999), Sęk z Dudkiem, Warszawa: Prószyński i S-ka.

Dziewoński Roman, Dziewoński Piotr (2007), Dożylnie o Dudku Edwardzie Dziewońskim, Warszawa: Świat Książki.

Eisler Jerzy (2006), Polski rok 1968, Warszawa: Instytut Pamięci Narodowej.

Fox Dorota (2004), Teatralny rodowód Lopka. Na marginesie szmoncesu, w: Żydzi w lustrze dramatu, teatru i krytyki teatralnej, red. E. Udalska, A. Tytkowska, Katowice: Wydawnictwo Uniwersytetu Śląskiego, s. 185-202.

Fox Dorota (2007), Kabarety i rewie międzywojennej Warszawy. Z prasowego archiwum Dwudziestolecia, Katowice: Wydawnictwo Uniwersytetu Śląskiego.

Grimstad Knut Andreas (2009), Polsko-żydowskie gry kabaretowe, czyli Juliana Tuwima próba akulturacji, przeł. M. Lachman i M. Lachman, „Teksty Drugie”, nr 3, s. $47-62$.

Kazimierz Krukowski, „Almanach Sceny Polskiej 1984/1985”, t. 26, Warszawa 1989, s. 270-271.

Korcelli Kazimierz, Rudzki Kazimierz, Słonimski Antoni (1972), Wspomnienia o kabarecie (rozmowa), „Dialog", nr 10, s. 119-125.

Krasowska Anna (2011), Obraz Żyda w szmoncesie kabaretowym, „Prace Językoznawcze", nr 13, s. 125-139.

Krasowska Anna (2013), Obraz dziecka żydowskiego w wybranych tekstach szmoncesowych, w: Żydowskie dziecko, red. A. Jeziorkowska-Polakowska, A. Karczewska, Lublin: Towarzystwo Naukowe Katolickiego Uniwersytetu Lubelskiego Jana Pawła II, s. 159-167.

Krasowska Anna (2013), Socjolingwistyczne i stylistyczne aspekty nazewnictwa Żydów w szmoncesie kabaretowym dwudziestolecia międzywojennego, w: Niejedno ma imię... Prace onomastyczne i dialektologiczne dedykowane Profesor Ewie Wolnicz-Pawłowskiej, red. E. Dzięgiel, T. Korpysz, Warszawa: Wydawnictwo UKSW, s. 229-245.

Krukowski Kazimierz (1958), Moja Warszawka, Warszawa: Filmowa Agencja Wydawnicza.

Krukowski Kazimierz (1982), Mała antologia kabaretu, Warszawa: Wydawnictwo Radia i Telewizji.

Krukowski Kazimierz (1987), Z Melpomena na emigracji, Warszawa: Czytelnik.

Michalski Dariusz (2007), Kazimierz Krukowski, w: D. Michalski, Powróćmy jak za dawnych lat... Historia polskiej muzyki rozrywkowej (1900-1939), Warszawa: Wydawnictwo Iskry, s. 373-405. 
Michnikowski Wiesław (2008), Poproszę zamiejscowq Lubartów czydzieściczy, rozm. A. Uścińska, „Teatr”, nr 12, s. 70-74.

Ryszard Marek (1959), Z szopki polityczno-literackiej 1958, „Odgłosy”, nr 15, s. 11.

Stępień Tomasz (1989), Kabaret Juliana Tuwima, Katowice: Wydawnictwo Śląsk.

Tom Konrad (1978), Jak się nie ma, co się lubi..., w: R.M. Groński, Jak w przedwojennym kabarecie, Warszawa: Wydawnictwo Artystyczne i Filmowe, s. 88-89.

Tuwim Julian (1978), Noc poślubna, w: R.M. Groński, Jak w przedwojennym kabarecie, Warszawa: Wydawnictwo Artystyczne i Filmowe, s. 76-78.

Tuwim Julian (2002), Kabaretiana, oprac. J. Stępień, Warszawa: Wydawnictwo Czytelnik.

Tynecki Jerzy (1988), Ryszard Wierzbowski 1936-1988, „Prace Polonistyczne”, t. 43, s. 361-367.

Uścińska Agnieszka (2012), Elegia starozakonna, czyli szmonces w kabarecie polskim jako żart z pogranicza kultur, w: Jaki jest kabaret?, red. D. Fox, J. Mikołajczyk, Katowice: Wydawnictwo Uniwersytetu Śląskiego, s. 93-114.

Uścińska Agnieszka (2014), Szmonces w polskim kabarecie dwudziestolecia międzywojennego, w: Humor polski, red. D. Brzozowska, W. Chłopicki, Kraków: Tertium, s. $495-517$.

\title{
"Jewish Elegy": \\ On Shmontses in the Polish People's Republic
}

\begin{abstract}
The article addresses the topic of shmontses in Poland after 1945, focusing on historical and political circumstances that significantly influenced the perception of this performative and literary genre. Shmontses - a form extremely popular in the interwar cabaret - drew patterns from Jewish humour. As the relevant cultural context was gradually vanishing, the genre became less frequent on stage. Despite that the pre-war works by Konrad Tom, Ludwik Lawiński and Julian Tuwim were included in the repertoire of cabaret "Dudek". A sketch referring to the Jewish themes appeared in the show of Television Theatre. It was entitled Cabaret Warietano, czyli XI Muza Juliana Tuwima (Cabaret Warietano, or 11th Muse of Julian Tuwim) and directed by Jerzy Dobrowolski. The author of the article also discusses the shmontses written by the young post-war writers - Wojciech Młynarski and Ryszard Marek (Ryszard Wierzbowski and Marek Groński).
\end{abstract}

Keywords: shmontses, cabaret, 1968 Polish political crisis, cabaret "Dudek", Television Theatre 